\title{
INTELLECTUAL CAPITAL, FIRM PERFORMANCE AND PRESIDENT DIRECTOR LEVEL OF EDUCATION AND SPECIALIZATION
}

\author{
Syarine Geannah Sietas \\ Luky Patricia Widianingsih* \\ Anastasia Filiana Ismawati \\ Universitas Ciputra, Citraland CBD Boulevard, Surabaya, Indonesia \\ *luky.patricia@ciputra.ac.id
}

ARTICLE INFO

Article history:

Received February 16, 2021

Revised July 25, 2021

Accepted September 8, 2021

Key words:

Intellectual Capital; Return on

Asset; CEO Education Level; CEO

Specialization; SOE

DOI:

https://doi.org/10.33508/jako.v14i1.3032

\begin{abstract}
A B S T R A C T
Research Purposes. This study was conducted to determine the effect of intellectual capital on company performance, with the level of education and specialization of the President Director as moderating variables.

Research Method. The sample used in this study is a non-financial stateowned company listed on the Indonesia Stock Exchange for the period 2015 2019. Data collection uses secondary data derived from company annual reports. Data analysis used simple linear regression and moderated regression using SPSS 25.

Research Result and Findings. This study indicates that intellectual capital has a positive effect on company performance as proxied by ROA. The President Director's educational background variables, namely education level, and specialization, cannot moderate the effect of intellectual capital on company performance.
\end{abstract}

\begin{abstract}
A B S T R A K
Tujuan Penelitian. Penelitian ini dilakukan untuk mengetahui pengaruh intellectual capital terhadap kinerja perusahaan, dengan jenjang pendidikan dan spesialisasi pendidikan Direktur Utama sebagai variabel moderasi.

Metode Penelitian. Sampel yang digunakan dalam penelitian ini adalah perusahaan SOE non keuangan yang terdaftar di Bursa Efek Indonesia periode tahun 2015-2019. Pengumpulan data menggunakan data sekunder yang berasal dari laporan tahunan perusahaan. Analisis data menggunakan regresi linier sederhana dan regresi moderasi dengan menggunakan SPSS 25. Hasil dan Temuan Penelitian. Hasil penelitian ini menunjukkan bahwa intellectual capital berpengaruh positif terhadap kinerja perusahaan yang diproksikan dengan ROA. Variabel latar belakang pendidikan Direktur Utama, yakni jenjang pendidikan dan spesialisasi pendidikan, tidak dapat memoderasi pengaruh intellectual capital terhadap kinerja perusahaan.
\end{abstract}

\section{INTRODUCTION}

State-Owned Enterprise (SOE) is one of the parties involved in Indonesia's economic activities, which plays a vital role in developing the national economy through state revenue and pursuing profit. Tax and dividend contributions make the role of SOEs in the Indonesian economy very significant. There is an increase in the number of SOE contributions from 2015-2019. SOE contributed IDR 202.6 trillion to the 2015 State Budget, then this amount increased by $0.74 \%$ in 2016. In 2017, there was an increase of $8.84 \%$ and again increased by $12.91 \%$ in 2018. An exceptionally significant increase occurred in 2019, which is $18.3 \%$. The increase in the contribution rate does not make the
Indonesian Ministry of SOE satisfied with the performance of SOE because there are still several SOEs that recorded a loss.

Changing the board of directors is one way by the Minister of SOE, Erick Thohir, to improve SOEs' poor performance. This change of the board of directors has been carried out since 2015 by 20142019 Minister of SOE, Rini Mariani. Until August 2020, Erick Thohir stated that the change of directors of SOEs had reached $90 \%$ and explained that this change of directors was intended to provide opportunities for companies to transform and improve their performance. Therefore, SOEs must show competitive advantages, demonstrate competitiveness, and improve their performance. 
Not only focusing on firm performance, in July 2020, the Directorate General of State Assets (DJKN) also added that there would be a calculation of Intellectual Property Rights or Intangible Assets of companies in Indonesia. This calculation is carried out because DJKN has identified that intangible assets can be a source of state revenue. The Director of Assessment of the DJKN, Kurniawan Nizar, also conveyed that the IPR assessment can increase a country's economy's competitiveness by optimizing existing intellectual property and intangible assets. This shows that as one of the company's resources, intellectual capital management is now the focus of the company's work as well because it can provide benefits for the company, which in turn can affect state profits.

The resource-based theory put forward by Wernerfelt (1984) discusses resources can improve company performance and create competitiveness. These resources can be in the form of tangible assets and intangible assets. In the last few decades, there has been a shift in the investment paradigm from tangible assets to intangible assets, which causes tangible assets to get significant attention from companies regarding their management (Puspitosari, 2016).

According to PSAK No. 19 The 2015 revision of Intangible Assets (Ikatan Akuntansi Indonesia, 2015), intangible assets are non-monetary assets that can be identified and do not have a physical form and are held for use in producing or delivering goods or services, leased to other parties, or for administrative purposes. It was also explained that intangible assets could include knowledge of trademarks, patents, and intellectual property licenses. In her book, Brooking (1998) uses the word "intellectual capital" to combine intangible assets that are essential for the running of a company (market assets, intellectual property assets, human-centered assets, and infrastructure assets). Stewart (1997), in (Ariantini Yuniarta and Sujana, 2017) also define intellectual capital as an intangible asset, such as knowledge to experience, that can create wealth for the company. Intellectual capital will reflect the company's resources to produce higher assets, which then create added value and lead to a sustainable competitive advantage, which can be in the form of product quality or other things. This competitive advantage will then increase the company's performance and value.

Many previous studies have examined the relationship between intellectual capital and company performance. Ariantini, Yuniarta and Sujana (2017) concluded that intellectual capital affects company performance. It is appropriately managed to impact the implementation of company strategy, which can also improve company performance. (Smriti and Das, 2018) carried out other research on intellectual capital and company performance. The research concludes that intellectual capital performance positively affects the company's profitability, productivity, sales, and market valuation. Several studies measure the influence of the VAIC components, such as research conducted by Puspitosari (2016). This research shows that the three components of intellectual capital, namely VACA, VAHU, and STVA, influence the company's ROA. Therefore, intellectual capital must be managed as well as possible to benefit the company.

Intellectual capital, measured by value-added, requires a calculation using the company's income and expenses. Therefore, good management is needed. Chief Executive Officer (CEO) is in the highest position in the company, making major company decisions and overseeing various company operations. CEO is in the key to a company responsible for the company performance (Celikyurt and Donmez, 2017). President Director is another term for CEO, with the same job description and responsibilities (Kwalomine, 2018). The President Director is in charge of regulating and organizing the entire company and making corporate strategy decisions that determine the company's processes. In Indonesia, the more often used term is the President Director (Sudana and Aristina, 2017). President Director is treated differently from intellectual capital because this study will only focus on the President Director's education for the variable, not on the salary value. The President Director as the company's controller and the education is thought to contribute to the relation of intellectual capital to the company's performance.

King, Srivastav and Williams (2016) wrote that the level of education (Undergraduate, Master, and Ph.D.) could indicate the President Director's education. President Director with high education levels are considered better because they can process information more quickly (Bantel and Jackson, 1989; Erlim and Juliana, 2017). President Director with an MBA (Master of Business Administration) and MM (Master Management) degrees have more knowledge about the company to make a better decision for company performance 
(Setiawan and Gestanti, 2018). Erlim and Juliana's research (2017) also concluded that the higher the President Director's level of education, the higher the company's performance. Due to the assumption that the higher the level of education, the more knowledge will be gained. This knowledge can then be used as a basis for decision making in the company to bring the company to better performance (Tullah, 2017)

The second educational indicator is the specialization or department taken by the President Director while pursuing the education level. The research results by Wulf and Stubner (2013), which are used for Erlim and Juliana's research (2017), divide President Director specialization into natural sciences and social sciences, which will affect President Director's behavior and mindset. President Directors with a natural sciences background will be more tied to their business and directly involved in the company's operational activities. In contrast, President Director with a social sciences background will see more of the big picture with complex organizational structures. In contrast to this theory, Erlim and Juliana's research (2017) concluded that the suitability of President Director specialization does not significantly affect company performance, so it only affects the behavior of the President Director. Another study that shows the level of negative influence is the Kwalomine study (2018). This study uses a specialization or major in economics and noneconomics as the President Director's background's focus to be tested for its effect on company performance. The results of the study show that the effect is not significant.

From the differences in the theory of Wulf and Stubner (2013); Erlim and Juliana (2017) and several previous research results, the authors see that the level of education and specialization of President Director does not have a direct effect on company performance but may affect the mindset of the President Director in making decisions. Also, there is a research gap conducted by Singla (2020), which concludes that VAIC and other components do not affect company ROA, thus allowing the emergence of other factors that can strengthen to prove the effect of intellectual capital on company performance. This reason then makes researchers interested in making the President Director's level of education and specialization into moderating variables.

Based on the background of the problem described, there are three problem formulations in this study: (1) Does intellectual capital affect the performance of state-owned companies? (2) Does the education level of the President Director as a moderating variable affect the relationship between intellectual capital and the performance of stateowned companies? And (3) Does the specialization of the President Director as a moderating variable affect the relationship between intellectual capital and the performance of state-owned companies?

\section{LITERATURE REVIEW AND HYPOTHESIS DEVELOPMENT}

Literature Review

Resource-based Theory

The resource-based theory by Wernerfelt (1984) states that resource is anything that can be considered a strength or weakness of the company. Barney (Barney, Wright and Ketchen Jr, 2001) also argues that these strategic assets must be valuable, rare, difficult to imitate, and non-substitutable. With these characteristics, the company's resources will help the company create strategies that take advantage of opportunities and ward off competitors' threats to imitate or seek alternatives to similar resources. One of the critical strategic assets is intellectual capital (Hermawan, 2018). Having intellectual capital means that the company has unique and valuable knowledge. Intellectual capital is said to be a strategic asset because it has a potential relationship with company performance. After all, the essential thing in today's economy is not the production of goods and services anymore, but the production of knowledge (Radjenovic and Bojan, 2017). Knowledge is a resource that is difficult to imitate. This knowledge can then be used to improve the quality of the products and services provided and enable innovation and more efficient business processes.

\section{Intellectual Capital}

The word "intellectual capital" is used to combine intangible assets that are important for running a company, which can increase the company's profits (Brooking, 1998). According to Brooking (1998), intellectual capital can be in the form of market assets, intellectual property assets, human-centered assets, and infrastructure assets. Stewart (1997, in Ariantini, Yuniarta and Sujana, 2017) defines intellectual capital as intellectual material such as knowledge, information, intellectual rights to experiences that can create wealth.

There are several methods of measuring intellectual capital by measuring added value, 
which was then used by Pulic (2000) to develop the VAIC (Value Added Intellectual Coefficient), model. This method focuses on value-added, which is the most objective indicator to assess business success and shows its ability to create value (value creation). Pulic (2000) classifies value-added as obtained from the difference between income and costs incurred by the company. Furthermore, the added value is divided into three categories, namely Human Capital (HC), Structural Capital (SC), and Capital Employed (CE).

Human capital (human resources) is the company's fundamentals, which include knowledge, skills, experience, competence, attitudes, commitment, and individual characteristics that are manifested in workability. Human capital assessment can be seen through the company's costs such as salaries, wages and allowances provided. Structural capital is the company's ability to support employees in producing optimal performance. Capital Employed is the financial capital owned by a company.

There are three relationships associated with this added value. The first relationship is VA and CE, called VACA (Value Added Capital Employed). VACA shows how much VA a unit of $\mathrm{CE}$ can produce. The second relationship is VA and HC, called VAHU (Value Added Human Capital). VAHU indicates how much VA can be generated with funds spent on labor. In other words, this relationship indicates the $\mathrm{HC}^{\prime} \mathrm{s}$ ability to create value within the firm. The last relationship is VA and SC, or it is called STVA (Structural Capital Coefficient). STVA shows SC's contribution to value creation by measuring the amount of SC needed to produce 1 rupiah of VA. The VAIC value can then be calculated after obtaining the VACA, VAHU, and STVA values by adding up all the coefficients.

$$
\begin{aligned}
& \mathrm{VA}=\text { OUT-IN } \\
& \mathrm{VACA}=\frac{V A}{C E} \\
& \mathrm{VAHU}=\frac{V A}{H C} \\
& \text { STVA }=\frac{S C}{V A} \\
& \mathrm{VAIC}=\mathrm{VACA}+\mathrm{VAHU}+\mathrm{STVA}
\end{aligned}
$$

Description:

$\mathrm{VA}=$ Value Added

OUT $=$ Output (total sales and other revenue)

IN = Input (selling expenses and other expenses)

VACA = Value Added Capital Coefficient

VAHU = Value Added Human Capital

STVA = Structural Capital Value Added

$\mathrm{VAIC}=$ Value Added Intellectual Coefficient

$\mathrm{CE}=$ Capital Employed

$\mathrm{HC}=$ Human Capital

$\mathrm{SC}=$ Structural Capital

The VAIC model measures the amount of value-added quantity created from each unit of resource. The higher the VAIC value, the higher the added value generated. Based on the Business Performance Indicator (BPI) (Soufyan, Sari, Nugroho and Amri 2018; Ulum, 2008), the VAIC score assessment can be categorized as follows:

1. VAIC score $\geq 3.00=$ Top Performers

2. VAIC score 2.00 2.99 = Good Performers

3. VAIC score 1.50 1.99 = Common Performers

4. VAIC score $<1.5=$ Bad Performers

\section{Firm Performance}

Company performance is a complete display of the company's condition in a certain period (Galib and Hidayat, 2018). Measurement of company performance is carried out to determine the achievement of company performance in utilizing company resources. This measurement can then be used for decision making. Many ways can be used to measure company performance, one of which is the profitability ratio. This study will use the Return on Asset (ROA) ratio to measure company performance. ROA is one of the profitability ratios widely used by information users (Puspitosari, 2016). ROA is used to measure the company's ability to generate profits with the company's assets (Solechan, 2017). The measurement is done by comparing the total assets with net income after tax. The use of net profit after tax makes ROA a tool for calculating the company's maximum profit. The better the return on assets, the better the company's performance. ROA is used in this study because it is in the researcher's interest to determine the effect of intellectual capital as an asset on its returns to the company.

$$
\mathrm{ROA}=\frac{\text { Net Income }}{\text { Total Assets }}
$$

\section{President Director's Level of Education}

The education level is how high a President Director's higher education academic program is, such as undergraduate, Masters, and Ph.D. (King, 
Srivastav and Williams, 2016). Learning at each level of education can provide knowledge and influence the behavior of the President Director. The undergraduate or undergraduate education provides essential training for the President's Director to develop his skills. Furthermore, at the Master or Masters Level, the President Director will focus more on his specialization and receive training related to problem-solving to train strategic thinking in providing solutions to existing problems. At the doctoral or Ph.D. level, graduates will carry out further research so that people who have a doctorate have technical expertise. Setiawan and Gestianti (2018) also examined the same thing. The study stated that the President Director with an MBA (Master of Business Administration) and MM (Master Management) has more knowledge about the company for better company performance decisions.

\section{Pesident Director's Specialization}

Wulf and Stubner (2013); Erlim and Juliana (2017) divide the Main Director's educational specialization into 2, namely natural science (engineering department) and social science (business department). Kwalomine (2018) carried out a similar division, which focuses on educational background into the economic and other (noneconomic) social fields. The field of economics consists of majoring in accounting, economics, management, and business. Non-economic fields consist of communications, geography, law, and others. This department or specialization then affects the characteristics and attitudes of the President Director. The President Director, who specializes in natural science (non-economics), tends to be directly involved in the company's operational activities and is easy to adapt to the challenges in companies with a low level of diversification. The President Director will focus on the synergy between results and processes. On the other hand, the President Director with a specialization background in social science (economics) can better see the big picture of the company focusing on a more complex organizational structure and the company's strategic decisions. The fields pursued in the President Director's education with the corporate industry can influence the decisions and strategies of the President Director for better company performance.

\section{Hypothesis Development}

Several researchers with mixed results have proved the relationship between intellectual capital and company performance. Based on Puspitosari's research (2016), the components of intellectual capital, namely VACA, VAHU, and STVA, significantly affect its ROA. This study concluded that VACA had the most substantial effect than the others. Other research conducted by Solechan (2017) concluded that VACA has a positive effect on ROA, VAHC has a negative effect on ROA, and VASC has a negative effect on ROA. International research was also carried out by Smriti and Das (2018) on companies in India. Using the VAIC method to measure intellectual capital, Smriti and Das (2018) concluded that VAIC is positively related to company performance, where VAIC plays a vital role in improving company performance and generating wealth and growth in the economy. From the relationship between variables and previous research, a hypothesis can be drawn:

H1: Intellectual Capital has a positive effect on company performance based on the ROA ratio of SOE.

There have been several previous studies examining the effect of the President Director's education on company performance. Erlim and Juliana's research (2017) proves that the level of education affects the President Director's ability in knowledge and performance, which can then affect the company's performance. Setiawan and Gestianti (2018) also examined the relationship between the President Director who has an MMMBA (Master Management or Master Business Administration) degree on funding decisions, investment, and company performance. From these studies, one of the findings is that the title has a positive effect on the company's ROA because it has more education in funding and investment decisions so that it can provide a high return for the company. It can be concluded that the higher the level of education of a President Director, it will produce right decisions through the education he has taken so that the company's performance will be even higher. From previous research and these conclusions, the following hypotheses can be drawn:

H2: The President Director's level of education strengthens the influence of Intellectual Capital on Company Performance based on the ROA Ratio in SOE. 
Erlim and Juliana (2017) examined the President Director's specialization or department's influence as an educational background that can influence the President Director's mindset and actions. The theoretical basis used states that the President Director with specialization by the company's industry will produce an appropriate strategy for better company performance. The study results conclude otherwise, namely that the President Director's education specialization does not affect company performance because whatever field the President Director takes can provide the same or not provide more significant performance. Another study was conducted by Kwalomine (2018), which divided specializations into economic and non-economic degrees. The study concluded that the President Director's education specialization has a significant negative effect on company performance (PKBL). From the theoretical basis and the results of previous research, it can be seen that the President Director's specialization does not directly affect company performance but can influence actions, mindsets and decision making related to company performance, so the following hypothesis can be drawn:

H3: The President Director's specialization in education strengthens the influence of intellectual capital on company performance based on the ROA ratio of SOE.

\section{Research Model}

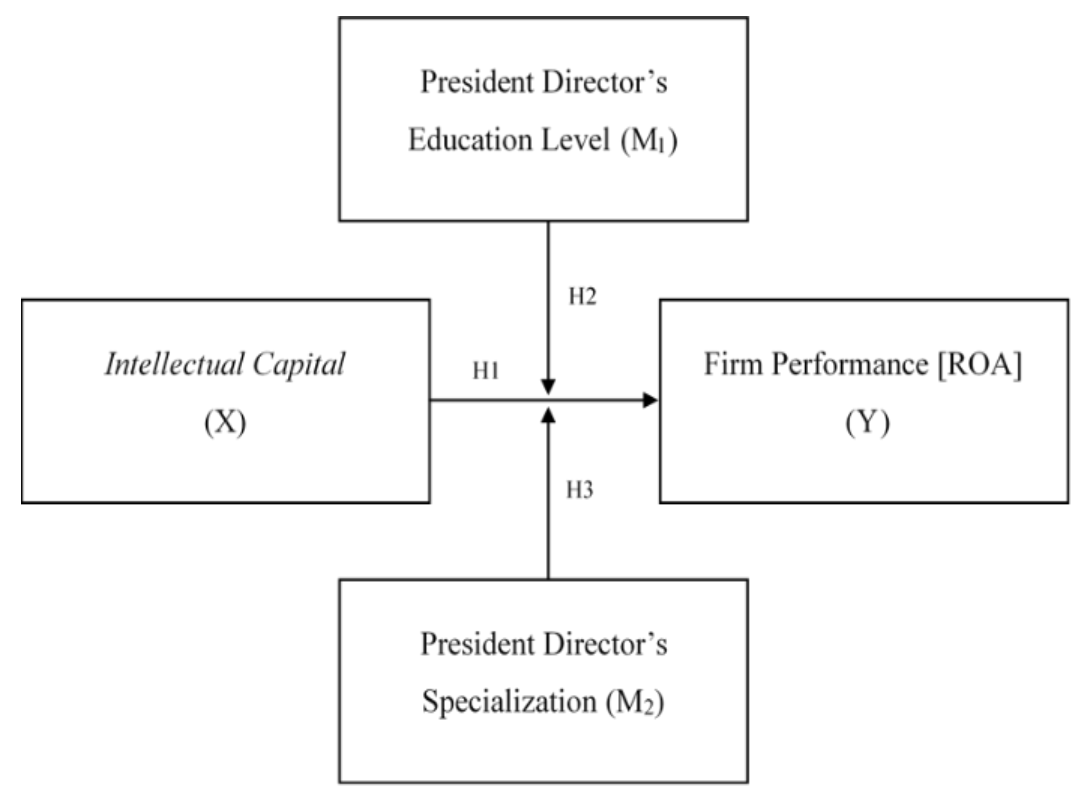

Image 1. Research Model

\section{RESEARCH METHOD}

\section{Population and Sample}

The population of this research is nonfinancial SOE listed on the Indonesia Stock Exchange from 2015-2019. The sampling method for this study is a non-probability method, which is purposive sampling with sample selection criteria as follows:

1. Non-financial SOE listed on the Indonesia Stock Exchange in 2015-2019.

2. Issuing complete annual financial reports for the period 2015-2019.

3. Complete annual reports are containing educational background information for the SOE.
One company was registered on the IDX in 2016, so it did not meet the purposive sampling requirements, so the company was excluded from the research sample. The final numbers of SOE used are 19 SOEs, with a total of 95 data.

\section{$\underline{\text { Research Variables }}$}

This study's dependent variable is company performance (ROA), while the independent variable used is intellectual capital. The intellectual capital will be measured using the VAIC (Value Added Intellectual Coefficient) method. This study also uses moderating variables, namely the 
President Director's education level (EDULVL), and specialization (EDUSPE).

\section{$\underline{\text { Research Paradigm }}$}

The type of research used is a quantitative approach. Numerical data will then be processed with statistical methods and linked to the theoretical basis to conclude the influence between variables (Sugiyono, 2019).

The analytical method used is descriptive statistics and classical assumption test; normality test, multicollinearity test, heteroscedasticity test, and autocorrelation test. Hypothesis testing is done by:

\section{Regression Analysis}

This study uses two regressions, namely simple linear regression analysis and moderated regression analysis. Linear regression analysis was conducted to determine the effect of intellectual capital on company performance (ROA). Moderation regression analysis uses an analytical approach that maintains the sample and provides a basis for controlling moderator variables (Ghozali, 2018) and is used to see the effect of the education level and specialization of the President Director. The measurements will compare the following regression equations:

1. Simple linear regression analysis equation model to test $\mathrm{H} 1$ :

$$
\mathrm{Y}=\mathrm{a}+\mathrm{b} 1 \mathrm{X} 1+\mathrm{e}
$$

2. Moderation regression analysis equation to test $\mathrm{H} 2$ :

$$
\mathrm{Y}=\mathrm{a}+\mathrm{b} 1 \mathrm{X} 1+\mathrm{b} 2 \mathrm{M} 1+\mathrm{b} 3 \mathrm{X} 1 \mathrm{M} 1+\mathrm{e}
$$

3. Moderation regression analysis equation to test $\mathrm{H} 3$ :

$$
\mathrm{Y}=\mathrm{a}+\mathrm{b} 1 \mathrm{X} 1+\mathrm{b} 2 \mathrm{M} 2+\mathrm{b} 3 \mathrm{X} 1 \mathrm{M} 2+\mathrm{e}
$$

\section{Description:}

$\mathrm{Y}=$ company performance (ROA)

$\mathrm{X} 1$ = Intellectual capital

M1 = Education level of President Director

M2 = Education specialization of the President

Director

$$
\begin{aligned}
& \text { b1 }=\text { Regression coefficient of variable X1 } \\
& \text { b2 }=\text { Regression coefficient of variable M1 } \\
& \text { b3 }=\text { Moderation regression coefficient } \\
& \text { a }=\text { Constant } \\
& \text { e }=\text { error }
\end{aligned}
$$

\section{F Test (Model Feasibility Test)}

This hypothesis test is also called the overall significance test of the observed regression line and an estimate of the relationship between variables. The $\mathrm{F}$ test aims to test the effect of the independent variable on the dependent variable and test the feasibility of the analysis model. (Ghozali, 2018). The regression model is declared feasible if the significance value is $<0.05$.

t-test

The t-test or partial test is used to test whether the dependent variable significantly affects the independent variable. The significance level is 0.5. A significance value $<0.5$ indicates that the independent variable affects the dependent variable. Conversely, if $>0.5$, then the independent variable has no significant effect on the dependent variable or, in other words, $\mathrm{H} 0$ is accepted (Ghozali 2018).

\section{RESULT AND DISCUSSION}

Result

Descriptive Analysis

Table 1. Descriptive Statistic

\begin{tabular}{lcccc}
\hline & Min & Max & Mean & $\begin{array}{c}\text { Std. } \\
\text { Dev. }\end{array}$ \\
\hline VAIC & $-115,28$ & 10,99 & $-5,3695$ & 23,541 \\
\hline EDULVL & 1,00 & 3,00 & 1,8000 &, 46935 \\
\hline SPESIALISASI &, 00 & 1,00 &, 5857 &, 49615 \\
\hline ROA &, 0009 &, 1308 &, 0300 &, 02367 \\
\hline
\end{tabular}

Table 1 shows the data for this study. The average VAIC value for SOEs is -5.3695 , which indicates that, overall, SOEs have not adequately managed their intellectual capital because they have not generated value-added for the company. The level of education variable has a value of having 16 samples for Undergraduate President Directors, 52 samples for Master President Directors, and 2 samples for Ph.D. President Directors. The specialization variable has 29 samples belonging to the President Directors with a non-economic education category and 41 samples belonging to the President Directors with economics education. The average ROA value is 0.300 with a standard deviation of 0.02367 , which means that SOEs as a whole have been able to make good use of their assets to generate profits for the company.

Normality Test

Table 2. Normality Test

\begin{tabular}{cccr}
\hline Model & Variable & $\mathrm{N}$ & $\begin{array}{c}\text { Asymp. Sig. (2- } \\
\text { tailed) }\end{array}$ \\
\hline 2 & [ROA_EDULVL] & 70 & 0.200 \\
\hline 3 & {$[$ ROA_EDUSPE] } & 70 & 0.200 \\
\hline
\end{tabular}

The normality test used for this moderation model is the Kolmogorov-Smirnov test. Table 2 
shows that the two moderation models, namely education level and education specialization, on ROA as a proxy for financial performance, have Asymp. Sig. (2-tailed) above 0.05, so it can be concluded that the two models are normally distributed and meet the normality test.

Multicollinearity Test

Table 3. Multicollinearity Test

\begin{tabular}{cccc}
\hline Model & Variable & $\mathrm{N}$ & VIF \\
\hline 2 & {$[$ ROA_EDULVL] } & 70 & 1.003 \\
\hline 3 & {$[$ ROA_EDUSPE] } & 70 & 1.009 \\
\hline
\end{tabular}

The multicollinearity test in this study will be based on the VIF value. VIF value $<10$ indicates that the moderation model is free of multicollinearity. Table 3 shows that the two moderation models above, namely education level and education specialization, have a VIF value $<10$, so it can be concluded that the moderation model is free of multicollinearity.

Heteroscadasticity Test

Table 4. Heteroscadasticity Test

\begin{tabular}{clr}
\hline Model & \multicolumn{1}{c}{ Variable } & Sig. \\
\hline 2 & VAIC & 0.406 \\
\hline & EDULVL & 0.394 \\
\hline 3 & VAIC & 0.297 \\
\hline & EDUSPE & 0.947 \\
\hline
\end{tabular}

The heteroscedasticity test in this study will use the Glejser test. The significance value $>0.05$ indicates that there are no symptoms of heteroscedasticity. Table 4 shows that the results of the significance of the two moderation models are $>0.05$, so it can be concluded that there are no symptoms of heteroscedasticity.

\section{Autocorrelation Test}

Table 5. Autocorrelation Test

\begin{tabular}{ccr}
\hline Model & Variable & \multicolumn{1}{c}{$\begin{array}{c}\text { Asymp. Sig. } \\
\text { (2-tailed) }\end{array}$} \\
\hline 2 & [ROA_EDULVL] & 0.054 \\
\hline 3 & [ROA_EDUSPE] & 0.054 \\
\hline
\end{tabular}

The autocorrelation test was performed using the Run test. The significance value $>0.05$ indicates that the regression model is free from autocorrelation. Table 5 shows that Asymp. Sig. (2tailed) is greater than 0.05 , so it can be concluded that the two moderation models are free from autocorrelation.
Linear Regression Test

Table 6. Simple Linear Regression

\begin{tabular}{lrll}
\hline \multicolumn{1}{c}{ Description } & Result & Significance \\
\hline $\mathrm{C}$ & 0,032 & \\
\hline VAIC $(\mathrm{X})$ & 4,089 & \\
\hline F-statistic & 16,717 & \\
\hline Sig. F & 0,000 & Significant \\
\hline Sig. $\mathrm{t}$ & 0,000 & Significant \\
\hline R-Square & 0,198 & \\
\hline Adjusted R-Square & 0,186 & \\
\hline
\end{tabular}

The regression model is declared feasible if the significance value $\mathrm{F}<0.05$. Based on table 6 , the $F$ test significance value for $\mathrm{ROA}(\mathrm{Y})$ is $0.000<0.05$. These results indicate that the intellectual capital (VAIC) research model on company performance (ROA) is feasible and tested further.

The regression equation model is then said to be significant if the significance value of $\mathrm{t}<0.05$. Based on table 6 , the significance value of the $t$ variable is $0.000<0.1$ to test the effect of VAIC on ROA. This shows that intellectual capital (VAIC) positively impacts company performance (ROA), so H1 is accepted.

Based on table 6 , the regression equation obtained is $\mathrm{Y}=0.032+4.089 \mathrm{X}$. The VAIC coefficient of 4.089 indicates that if there is an increase in 1 unit of VAIC, the ROA will increase by 4.089 . This means that if the intellectual capital increases or has added value to the company, its performance (ROA) will also increase. The adjusted $\mathrm{R}$ square number shows the coefficient of determination or the independent variable's role in the relationship with the dependent variable. The adjusted $\mathrm{R}$ square figure of 0.186 shows that only $18.6 \%$ of variable $Y$ can be explained by variable $X$, and other factors explain the rest.

Moderate Regression Test

Table 7. Moderate Regression Test I

\begin{tabular}{lrl}
\hline \multicolumn{1}{c}{ Description } & Result & Significance \\
\hline $\mathrm{C}$ & 0,057 & \\
\hline VAIC $(\mathrm{X})$ & 1,326 & \\
\hline EDULVL $\left(\mathrm{M}_{1}\right)$ & $-3,373$ & \\
\hline VAIC*EDULVL & - & \\
\hline$\left(\mathrm{X}^{*} \mathrm{M}_{1}\right)$ & 0,081 & \\
\hline F-statistic & 10,219 & \\
\hline Sig. $\mathrm{F}$ & 0,000 & Significant \\
\hline Sig. $\mathrm{t}$ & 0,936 & Not Significant \\
\hline R-Square & 0,317 & \\
\hline Adjusted R-Square & 0,286 & \\
\hline
\end{tabular}


Based on table 7, the significance value for the $\mathrm{F}$ test between intellectual capital (VAIC) and the level of education of the President Director on company performance $(\mathrm{ROA})$ is $0,000<0.05$. These results indicate that the intellectual capital research model (VAIC) and the President Director's level of education as moderating variables on company performance (ROA) are feasible and can be tested further.

Table 7 also shows that the $t$ significance value for the moderate interaction variable of intellectual capital (VAIC) and the level of education of the President Director is $0.936>0.05$, which means that the moderating variable for the level of education of the President Director is not significant, so H2 is rejected. This shows that the President Director's level of education cannot moderate the effect of intellectual capital (VAIC) on company performance (ROA).

Table 8. Moderate Regression Test II

\begin{tabular}{lrll}
\hline \multicolumn{1}{c}{ Description } & Result & Significance \\
\hline $\mathrm{C}$ & 0,036 & \\
\hline VAIC $(\mathrm{X})$ & 2,450 & \\
\hline EDUSPE $\left(\mathrm{M}_{2}\right)$ & $-1,765$ & \\
\hline VAIC*EDUSPE $\left(\mathrm{X}^{*} \mathrm{M}_{2}\right)$ & $-0,101$ & \\
\hline F-statistic & 6,720 & \\
\hline Sig. $\mathrm{F}$ & 0,001 & Significant \\
\hline Sig. $\mathrm{t}$ & 0,920 & Not Significant \\
\hline R-Square & 0,234 & \\
\hline Adjusted R-Square & 0,199 & \\
\hline
\end{tabular}

Based on table 8, the significance value for the F test between intellectual capital (VAIC) and the President Director's education specialization on company performance (ROA) is $0.001<0.05$. These results indicate that the intellectual capital research model (VAIC) and the President Director's education specialization as moderating variables on company performance (ROA) are feasible and further tested.

The significance value of $t$ in table 8 for the moderate interaction variable of intellectual capital (VAIC) and the education specialization of the President Director is $0.920>0.05$, which means that the moderation variable for the level of education of the President Director is not significant, so H3 is rejected. This shows that the President Director's specialization in education cannot moderate intellectual capital (VAIC) on company performance (ROA).
Discussion

Effect of Intellectual Capital on Firm Performance

The results of statistical tests of this study indicate that intellectual capital has a positive and significant effect on company performance (ROA) so that the H1 hypothesis in this study is accepted. This shows that intellectual capital can improve company performance. These findings are in line with research conducted by Ariantini, Yuniarta and Sujana (2017); Smriti and Das (2018); Puspitosari (2016), which show that intellectual capital has a significant effect on company performance. With good management of Human Capital, Structural Capital, and Employed Capital, these components can bring added value to the company, one of which is company profits. The increase in earnings from state-owned companies, which are stateowned companies, will also increase state revenue.

This study's results are also following the Resource-based Theory by Wernerfelt (1984), which states that resources, one of which is intellectual capital, can improve company performance and create competitiveness. With the nature of valuable, rare, difficult to imitate, and cannot be replaced, the company will get more opportunities than its competitors. This is also implemented by one of the SOE in Indonesia, namely PT Pembangunan Perumahan Tbk. PT Pembangunan Perumahan Tbk realizes that talent development is an important key to be competitive. To produce superior human resources, PT Pembangunan Perumahan Tbk then provides several programs, such as Certified Business Management, in collaboration with several universities and colleges to occupy strategic positions in the company (Miftahudin, 2020). Another program is the provision of corporate cultural values, namely Trustworthy, Competent, Harmonious, Loyal, Adaptive, and Collaborative (AKHLAK), to all employees, to behave following company goals and can support future business growth. This focus on human resources can then be seen from the VAIC and ROA scores of PT Pembangunan Perumahan Tbk, which have always been positive in the last five years, indicating that the costs incurred by the company provide added value to the company.

Overall, the research results indicate that Indonesian SOEs' intellectual capital has not been used optimally from the final value of the SOE's VAIC with an average value of -5.3695 . Based on the Business Performance Indicator, a VAIC score above 1.5 is common to top performers, and a VAIC score below 1.5 indicates bad performers (Soufyan, Sari, Nugroho and Amri, 2018; Ulum, 
2008) Of the 70 research samples, 28 samples had a VAIC value above 1.5. This proves that most SOEs in Indonesia has not managed their intellectual capital optimally. It can also be seen from the number of employee expenses, ranging from salaries, wages, benefits, and other costs, but it is not proportional to the current year's profit generated by the company.

Judging from the ROA value, the average value shows a value of 0.034060 , which means that all SOEs have been able to provide positive performance when assessed from their return rate. There was a significant decrease in the average ROA of the SOEin 2019 to $2.62 \%$ from $4.05 \%$ in the previous year. According to the Director-General of State Assets, Isa Rachmatarwata, the government has estimated this decline (Wildan, 2019). This is because the funds obtained from the government are focused on non-commercial activities to meet demands from the government. Upon this request, the government did not expect a high ROA for that year from SOE, so that SOE performance was only assessed by the projects they had worked on.

From the results of this study, intellectual capital has an effect on company performance, so that if the company manages intellectual capital better, the company's performance, as seen from the ROA, will also increase. The focus on intellectual capital management has been conveyed by the Minister of SOE, Erick Thohir, who has required the management of company employees' talent through incubation, training, and other facilities (Hermawan, 2020). These events related to talent development can cultivate an innovative work climate so that human resources can continue to create breakthroughs and new opportunities in the SOE environment.

Effect of Intellectual Capital on Firm Performance with President Director's Level of Education as moderating variable

This study indicates that the level of education of the President Director cannot moderate the relationship between intellectual capital and company performance (ROA). This means that the high level or education level of a President Director cannot strengthen or weaken intellectual capital's influence on company performance.

Several previous studies by Erlim and Juliana (2017); Setiawan and Gestianti (2018); Saidu (2019); Tullah (2017) stated that there was a significant positive effect on the level of education of the President Director on company performance.
Theoretically, the President Director's level of education can affect the abilities and knowledge that can then affect the company's performance. This is because a broad perspective is needed to make decisions so that the President Director with higher education will have more comprehensive insight and make better decisions (Tullah, 2017).

However, from the results of this study, the President Director's level of education cannot moderate the relationship between intellectual capital and company performance. This difference indicates that the President Director's level of education can have a more direct influence on company performance rather than moderating between variables. Bhagat, Bolton and Subramanian (2010) also added that the President Director's education has a weak relationship with company performance. This is presumably because education level is an inadequate benchmark to measure the ability of the President Director. Educational background does play an essential role in recruiting the President Director because it is still included in evaluating a presidential candidate. But there are also several other factors such as interpersonal skills, the ability to lead, and understanding a strategic vision, which is more than just a measure of education level.

From the data results, 52 SOEs President Directors have had a master's degree, 48\% (25 companies) of whom had negative VAIC numbers during the President Director's leadership. On the other hand, of the 15 President Directors of SOEs with a bachelor's degree, only five companies had negative VAIC scores. From the ROA value, companies with a President Director who graduated from $\mathrm{S} 1$ also have a higher average ROA, namely $4.03 \%$, compared to the President Director who graduated from S2 and S3. So it can be concluded that a President Director with a high level of education does not necessarily give a high VAIC score and company performance, so it cannot moderate the relationship between intellectual capital and company performance (ROA).

Effect of Intellectual Capital on Firm Performance with President Director's Specialization as moderating variable

The results of this study indicate that the President Director's specialization in education cannot moderate the relationship between intellectual capital and company performance (ROA). This result is indicated by a significance value $>0.05$ so that the hypothesis $\mathrm{H} 3$ is rejected. 
This means that a President Director's specialization, whether economic or non-economic, cannot strengthen or weaken the effect of intellectual capital on company performance.

Theoretically, specialization can influence the characteristics and attitudes of the President Director. The President Director with an economic background will be superior in seeing the big picture and determining its strategy compared to the President Director with a non-economic education background (Wulf and Stubner, 2013; Erlim and Juliana 2017). Previous research by Erlim and Juliana (2017); Kwalomine (2018) also concluded that the President Director's education specialization, whether it is by the field or not, or economics, does not significantly differentiate the company performance. This shows that the President Director's education specialization does not affect, either directly or as a moderating variable, company performance.

Bhagat, Bolton and Subramanian (2010) wrote that most companies choose a President Director with the same educational specialization background as the previous president. This shows that specialization education is one of the company's essential qualifications but does not guarantee that there will be no failures in the company, so it is also a weak benchmark to measure the ability of the President Director.

From the 43 President Directors' data result with economic education specialization, 44.18\% (19 companies) produced negative VAIC numbers during their period. On the other hand, of the 27 President Directors who specialize in non-economic education, only 11 companies had a negative VAIC score. From the ROA value, companies with a President Director who has a non-economic education background also have a higher average ROA, namely $3.55 \%$, compared to the President Director with a specialization in economic education, which is only $2.65 \%$. This shows that a President Director's economic specialization does not necessarily result in a good VAIC number and high ROA. Therefore, for this study, the President Director's education specialization cannot moderate the relationship between intellectual capital and company performance.

\section{CONCLUSION}

This study concludes that intellectual capital affects the company performance (ROA) of SOE in Indonesia. This indicates that the company must manage and develop intellectual capital well because the added value generated can create a competitive advantage, improving the company's performance. This study also concluded that the two factors of the President Director's educational background, namely education level, and specialization, cannot strengthen or weaken the relationship between intellectual capital and company performance.

This research can be used as input for the company to optimize the company's intellectual capital, one of which is the cost efficiency associated with human capital. This optimization will then have an impact on better company performance through the added value generated. Various programs for employee training can be carried out to be more developed and generate more added value for the company. In addition, because President Director's education as a moderating variable cannot strengthen or weaken the relationship of intellectual capital to ROA, companies can make other indicators to measure the President Director's ability. One example is the President Director's work experience (as in GarcésGaldeano and García-Olaverri, 2019), which can affect his knowledge of the industry to improve company performance.

\section{REFERENCES}

Ariantini, I. G. A., Yuniarta, G. A. and Sujana, E. (2017). Pengaruh Intellectual Capital, Corporate Social Responsibility, dan Good Corporate Governance Terhadap Kinerja Perusahaan (Studi Kasus Pada Perusahaan Manufaktur yang Terdaftar di Bursa Efek Indonesia tahun 2011-2015). Jurnal Ilmiah Mahasiswa Akuntansi Undiksha, 7(1), 1-11.

Bantel, K. A., and Jackson, S. E. (1989). Top management and innovations in banking: Does the composition of the top team make a difference? Strategic Management Journal, 10(S1), 107-124.

Barney, J., Wright, M., and Ketchen Jr., D. J. (2001). The Resource-Based View of the Firm: Ten Years After 1991. Journal of Management, 27(6), 625-641.

Bhagat, S., Bolton, B. J., and Subramanian, A. (2010). CEO Education, CEO Turnover, and Firm Performance. Didapatkan dari https://papers.ssrn.com/sol3/papers.cfm?ab stract_id=1670219, 05 Januari 2021, pukul 20.45 WIB.

Brooking, A. (1998). Intellectual Capital. London: International Thomson Business Press. 
Celikyurt, U. and Donmez, B. (2017). Engineer CEOs and Firm Performance in BIST Mmanufacturing Firms. Didapatkan dari https://papers.ssrn.com/sol3/papers.cfm?ab stract_id=2943710, 08 Desember 2020, pukul 13:20 WIB.

Erlim, K. W., and Juliana, R. (2017). Pendidikan CEO Terhadap Performa Perusahaan di Indonesia. Jurnal Manajemen Maranatha, 16(2), 177-186.

Galib, M. and Hidayat, M. (2018). Analisis Kinerja Perusahaan dengan Menggunakan Pendekatan Balanced Scorecard pada PT. Bosowa Propertindo. SEIKO: Journal of Management $\mathcal{E}$ Business, 2(1), 92-112.

Garcés-Galdeano, L., and García-Olaverri, C. (2019). The Hidden Value of Intangibles: Do CEO Characteristics Matter? International Journal of Manpower, 40(6), 1075-1091.

Ghozali, I. (2018). Aplikasi Analisis Multivariate dengan Program IBM SPSS 25. Semarang: Badan Penerbit Universitas Diponegoro.

Hermawan, D. (2020). Setahun Erick Thohir Menteri SOE: Ino-vasi Pengelolaan Talenta Karyawan Men-jadi Keharusan. Didapat dari https://www.pikiran-

rakyat.com/ekonomi/pr-01899922/setahunerick-thohir-menteri-SOE-inovasipengelolaan-talenta-karyawan-menjadikeharusan, 27 Desember 2020, pukul 12:30 WIB.

Hermawan, S. (2018). Makna Intellectual Capital Perspektif The Role Theory dan The Resource Based Theory. EKUITAS (Jurnal Ekonomi Dan Keuangan), 17(2), 256-275.

Ikatan Akuntansi Indonesia. (2015). Standar Akuntansi Keuangan. Jakarta: Ikatan Akuntan Indonesia.

King, T., Srivastav, A. and Williams, J. (2016). What's in an Education? Implications of CEO Education for Bank Performance. Journal of Corporate Finance, 37, 287-308.

Kwalomine, A. L. (2018). Pendidikan, Masa Jabatan Direktur Utama dan Pengungkapan Corporate Sosial Responsibility (CSR). Jurnal Riset Akuntansi Terpadu, 11(1), 72-82.

Miftahudin, H. (2020). PTPP Tingkatkan Daya Saing Lewat SDM Unggul. Didapat dari https://www.medcom.id/ekonomi/bisnis/8 N0jYpYk-ptpp-tingkatkan-daya-saing-lewatsdm-unggul, 10 Januari 2021, pukul 17:35 WIB.
Pulic, A. (2000). VAIC ${ }^{\mathrm{TM}}$ an Accounting Tool for IC Management. International Journal of Technology Management, 20(5-8), 702-714.

Puspitosari, I. (2016). Pengaruh Modal Intelektual terhadap Kinerja Keuangan pada Sektor Perbankan. Jurnal EBBANK, 7(1), 43-53.

Radjenovic, T., and Bojan, K. (2017). Intellectual Capital as the Source of Competitive Advantage: The Resource-Based View. Facta Universitatis, Series Economics and Organization, 14(2), 127-137.

Saidu, S. (2019). CEO Characteristics and Firm Performance: Focus on Origin, Education and Ownership. Journal of Global Entrepreneurship Research, 9(1), 1-15.

Setiawan, R., and Gestanti, L. (2018). CEO Education, Financial Decision and Firm Performance. Jurnal Manajemen Teori dan Terapan, 11(3), 193-206.

Singla, H. K. (2020). Does VAIC Affect the Profitability and Value of Real Estate and Infrastructure Firms in India? A Panel Data Investigation. Journal of Intellectual Capital, 21(3), 309-331.

Smriti, N., and Das, N. (2018). The Impact of Intellectual Capital on Firm Performance: A Study of Indian Firms Listed in COSPI. Journal of Intellectual Capital, 19(5), 935-964.

Solechan, A. (2017). Pengaruh Efisiensi Modal Intelektual Terhadap Kinerja Keuangan Perusahaan di Indonesia. Jurnal Kajian Akuntansi, 1(1), 87-100.

Soufyan, D. A., Sari, D. M., Nugroho, Y. and Amri, A. (2018). VAIC ${ }^{\mathrm{TM}}$ Perusahaan Pertambangan Terindeks LQ45 di Bursa Efek Indonesia. AKBIS: Media Riset Akuntansi dan Bisnis, 2(1), 28-36.

Sudana, I. M., and Aristina, N. P. N. (2017). Chief Executive Officer (CEO) Power, CEO Keluarga, dan Nilai IPO Premium Perusahaan Keluarga di Indonesia. Jurnal Akuntansi, 21(2), 219-231.

Sugiyono. (2019). Metode Penelitian Kuantitatif Kualitatif dan RED. Bandung: Alfabeta.

Tullah, N. A. J. (2017). Pengaruh Gender dan Latar Belakang Pendidikan CEO Terhadap Kinerja Keuangan Perusahaan Go Publik yang Terdaftar di Bursa Efek Indonesia. Jurnal Akuntansi AKUNESA, 6(1), 1-20.

Ulum, I. (2008). Intellectual Capital Performance Sektor Perbankan di Indonesia. Jurnal Akuntansi dan Keuangan, 10(2), 77-84. 
Wernerfelt, B. (1984). A Resource-Based View of the Firm. Strategic Management Journal, 5(2), 171180.

Wildan, M. (2019). Penurunan ROA dan ROE SOE Telah Sesuai Perkiraan. Didapatkan dari https://ekonomi.bisnis.com/read/20190909/ 9/1146254/penurunan-roa-dan-roe-SOEtelah-sesuai-perkiraan, 20 Januari 2021, pukul 20:30 WIB.

Wulf, T., and Stubner, S. (2013). Position-Specific Knowledge, New CEO Learning and Firm Performance. European Journal of International Management, 7(1), 6-30. 